\title{
Genetic characterisation of a cohort of children clinically labelled as GH or IGF1 insensitive: diagnostic value of serum IGF1 and height at presentation
}

\author{
Helen L Storr ${ }^{\dagger}$, Leo Dunkel, Julia Kowalczyk, Martin O Savage and \\ Louise A Metherell \\ Barts and the London School of Medicine and Dentistry, William Harvey Research Institute, \\ Centre for Endocrinology, Queen Mary University of London, London, UK \\ ${ }^{\dagger}$ Helen Storr is now at Centre for Endocrinology, John Vane Science Centre, Charterhouse Square, \\ London EC1M 6BQ, UK
}

\author{
Correspondence \\ should be addressed \\ to H L Storr \\ Email \\ h.l.storr@qmul.ac.uk
}

\begin{abstract}
Objective and design: GH insensitivity (GHI) encompasses growth failure, low serum IGF1 and normal/elevated serum GH. By contrast, IGF1 insensitivity results in pre- and postnatal growth failure associated with relatively high IGF1 levels. From 2008 to 2013, 72 patients from 68 families (45M), mean age 7.1 years (0.4-17.0) with short stature (mean height SDS - 3.9; range -9.4 to -1.5$)$, were referred for sequencing.

Methods: As a genetics referral centre, we have sequenced appropriate candidate genes (GHR, including its pseudoexon (6 6 ) , STAT5B, IGFALS, IGF1, IGF1R, OBSL1, CUL7 and CCDC8) in subjects referred with suspected GHI ( $n=69)$ or IGF1 insensitivity $(n=3)$.

Results: Mean serum IGF1 SDS was -2.7 (range -0.9 to -8.2 ) in GHI patients and 2.0, 3.7 and 4.4 in patients with suspected IGF1 insensitivity. Out of $69 \mathrm{GHI}$ patients, 16 (23\%) (19\% families) had mutations in GH-IGF1 axis genes: homozygous GHR ( $n=13 ; 66 \Psi$, two novel IVS5ds $+1 \mathrm{G}$ to A) and homozygous IGFALS ( $n=3$; one novel c.1291delT). In the GHI groups, two homozygous OBSL1 mutations were also identified (height SDS -4.9 and -5.7 ) and two patients had hypomethylation in imprinting control region 1 in 11 p15 or mUPD7 consistent with Silver-Russell syndrome (SRS) (height SDS - 3.7 and - 4.3). A novel heterozygous IGF1R (c.112G > A) mutation was identified in one out of three (33\%) IGF1-insensitive subjects.

Conclusion: Genotyping contributed to the diagnosis of children with suspected GHI and IGF1 insensitivity, particularly in the GHI subjects with low serum IGF1 SDS $(<-2.0)$ and height SDS $(<-2.5)$. Diagnoses with similar phenotypes included SRS and 3-M syndrome. In 71\% patients, no diagnosis was defined justifying further genetic investigation.
\end{abstract}

\section{Introduction}

Disorders of growth hormone $(\mathrm{GH})$ action frequently present with short stature in childhood and, although they affect a relatively small number of patients, the growth failure is often clinically significant and may be extreme (1). The clinical entity of GH insensitivity (GHI) was first described by Laron et al. (2) and the phenotype reported, known as Laron syndrome, was subsequently demonstrated to be caused by homozygous or compound heterozygous mutations of the $\mathrm{GH}$ receptor (GHR) gene $(3,4)$. These reports heralded the characterisation, using single gene sequencing, of defects in genes coding for functional proteins in the $\mathrm{GH}$-insulin-like growth factor 1 (IGF1) axis, which regulate the physiological actions of GH. Key biochemical features in patients with GHI are
(C) 2015 European Society of Endocrinology Printed in Great Britain
Published by Bioscientifica Ltd. 
normal or increased serum GH and low IGF1 (5). GHI can also be due to defects in genes encoding the post-GHR signalling protein, STAT5b $(6,7)$, IGF1 $(8,9)$ and the acidlabile subunit (ALS) $(10,11)$. Heterozygous IGF1 receptor (IGF1R) mutations $(12,13)$ have also been reported $(14,15)$ and are characterised by IGF1 insensitivity. In contrast to the clinical presentation of GHI, the main predictors of IGF1 insensitivity are: pre- and postnatal growth failure, relatively high IGF1 levels, small head size, developmental delay and micrognathia $(16,17)$. Additionally, the use of a clinical scoring system may aid the detection of IGF1R gene variants in children born small for gestational age (SGA) (16). Rarely, IGF1 levels may be low in patients with IGF1R defects (17). The identification of mutations in these genes has contributed to the clarification of the physiology of linear growth.

From the clinical perspective, it is of interest that, in defects of GH and IGF1 action, a continuum of clinical and biochemical abnormalities has emerged, ranging from extreme growth failure with recognisable dysmorphic features and severe GHI or IGF1 insensitivity to mild short stature with more subtle biochemical changes (18). Although no relationship was initially demonstrated between height and the type of homozygous GHR mutation in subjects with extreme GHI (19), the investigation of a broader range of GHI subjects (20) led to the discovery of dominant negative heterozygous splice site GHR mutations (21) and an intronic pseudoexon GHR mutation $(22,23)$ in subjects with a milder degree of short stature.

It is the variation of the clinical and biochemical features, which presents the clinician with the challenge of investigating patients with GHI or IGF1 insensitivity to identify known or potentially novel genetic abnormalities. A higher prevalence of genetic variants, identified by single gene sequencing, has been reported in children with heights $<-2.5$ SDS compared with less severely affected subjects (24). However, although this is a logical hypothesis, these results need confirmation. We report our experience as a reference genetic centre of sequencing candidate genes in 72 subjects ( 68 families) with suspected GHI or IGF1 insensitivity referred for genetic analysis.

\section{Subjects and methods}

\section{Patients}

The Endocrine Centre at the William Harvey Research Institute in London has become a referral laboratory for the investigation of genetic defects in children with short stature. Between 2008 and 2013, we received DNA samples from a series of 76 subjects; four subjects were not tested as GHI or IGF1 insensitivity was excluded clinically and biochemically (Fig. 1). Genetic sequencing was undertaken on 72 patients from 68 families (45 males and 27 females), mean age 7.1 years (0.4-17.0) with short stature (mean height SDS -3.9 ; range -9.4 to -1.5 ). Sixty-nine of the subjects were labelled as having GHI, i.e. low serum IGF1 and normal or high GH levels (groups 1-3; Fig. 1) with mean height SDS -3.9 (range -9.4 to -1.5 ). The remaining three subjects had features of IGF1 insensitivity (height SDS $-2.4,-3.1$ and -3.9 ). Samples were referred from: UK $(n=50)$, Kuwait $(n=6)$, Poland $(n=7)$, Germany $(n=3)$, Egypt $(n=2)$, Croatia $(n=1)$, Italy $(n=1)$, India $(n=1)$ and Belgium $(n=1)$. Birth weight, height and BMI data were expressed as SDS according to the appropriate national standards. Patients were investigated in their home institutions and the referring physicians completed a proforma detailing clinical and biochemical data at the time of sending the DNA sample. The referring clinicians excluded causes of secondary GHI, including undernutrition.

\section{Biochemical tests}

Serum IGF1 levels were measured in the referring institutions before DNA samples were sent for genotyping. For this reason, determination of serum IGF1 concentrations in a central laboratory was not possible. A number of different assays were used, depending on the centre. IGF1 values were expressed as SDS based on the age and sex appropriate reference range provided by the institution. Mean serum IGF1 SDS was -2.7 (range -0.9 to -8.2 ) in patients with suspected GHI and 2.0, 3.7 and 4.4 in patients with suspected IGF1 insensitivity. In 20 out of 72 (28\%) GHI subjects, the serum IGF1 was undetectable (less than the lower limit of the assay); therefore, the value at the lower limit of the assay was used to calculate the IGF1 SDS for these individuals. GH secretion was assessed at the referral centres and was normal in all subjects, i.e. a peak value during pharmacological stimulation $\geq 7 \mu \mathrm{g} / \mathrm{l}$ (mean 25.9, range $7.0-119.0 ; n=63$ ) or a basal value $\geq 10 \mu \mathrm{g} / \mathrm{l}$ (mean $84.0 \mu \mathrm{g} / \mathrm{l}$, range $10.0-398.0 ; n=9)$.

\section{Categorisation of subjects and genetic analysis}

Subjects were divided into four groups based on the suspected diagnosis, i.e. GHI or IGF1 insensitivity, height and IGF1 SDS (Fig. 1). Patients with suspected GHI were 


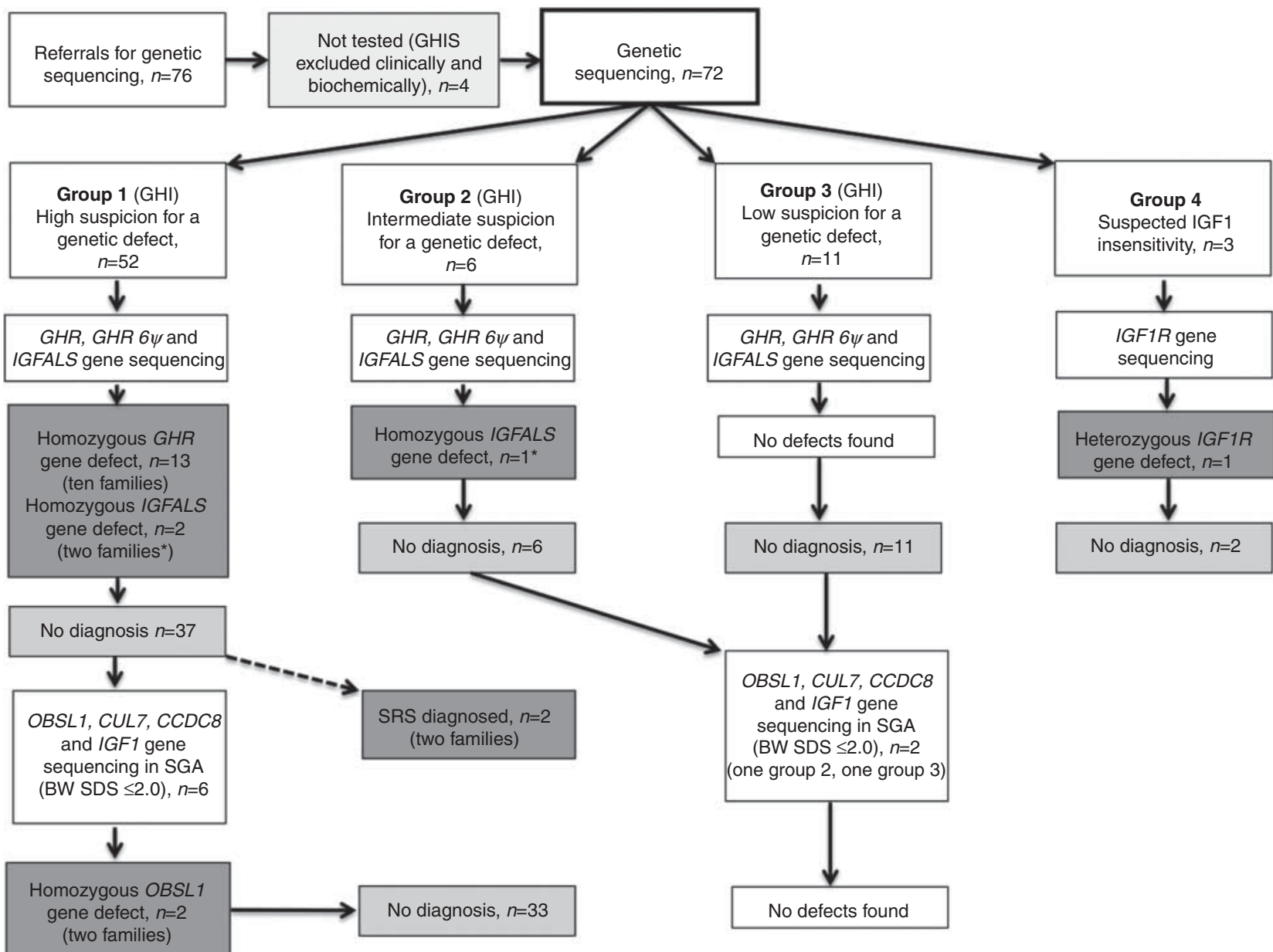

\section{Figure 1}

Patients referred for genetic sequencing and the outcome. Group 1, GHI - high suspicion for genetic defect (height SDS $\leq-2.5$, IGF1 SDS $\leq-2.0) n=52$; group $2, \mathrm{GHI}$ - intermediate suspicion for genetic defect (height SDS $\leq-2.5$, IGF1 SDS -1.9 or -2.0$) n=6$; group 3, GHI - low suspicion for genetic defect (height SDS -1.5 to -2.5 , IGF1 SDS $\leq-2.0$ ) $n=11$ and group 4, suspected IGF1 insensitivity (height SDS $\leq-2.0$, IGF1 SDS $\geq 2.0$ ) $n=3$. GHI, growth hormone insensitivity; GHR, GH receptor

allocated to groups $1-3$ (total $n=69$ ). Group 4 included patients with suspected IGF1 insensitivity $(n=3)$. Group 1 , GHI with high suspicion for a genetic defect (height SDS $\leq-2.5$, IGF1 SDS $\leq-2.0) n=52$; group 2 , GHIS with intermediate suspicion for a genetic defect (height SDS $\leq-2.5$, IGF1 SDS -1.9 or -2.0$) n=6$; group 3 , GHIS with low suspicion for a genetic defect (height SDS -1.5 to -2.5 , IGF1 SDS $\leq-2.0) n=11$ and group 4 , suspected IGF1 insensitivity (height SDS $\leq-2.0$, IGF1 SDS $\geq 2.0$ ) $n=3$. The genetic analysis undertaken on the subjects

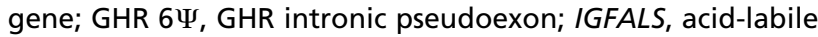
subunit gene; IGF1, insulin-like growth factor 1 gene; OBSL1, obscurin-like 1 gene; CUL7, cullin 7 gene; CCDC8, coiled-coil domain containing 8 gene; SGA, small for gestational age; SRS, Silver-Russell syndrome. *Two individuals with a homozygous IGFALS gene defect are siblings (subjects 14 and 15 in Table 1) one is in group 1 and the other is in group 3. Therefore, the three IGFALS gene defects are found in two families.

depended on the clinical and biochemical features (Fig. 1).

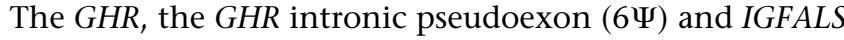
genes were sequenced in all patients with suspected GHI (groups 1-3). GHI subjects (groups 1-3) with evidence of immunodeficiency and/or atopy/eczema also underwent STAT5B sequencing $(n=7)$. The IGF1R gene was only analysed in patients with suspected IGF1 insensitivity (group 4). Following initial gene sequencing, GHI patients (groups 1-3) who did not have a molecular diagnosis and were born SGA (birth weight SDS $\leq-2.0) \quad(n=8)$ 
underwent IGF1, OBSL1, CUL7 and CCDC8 gene analysis (group 1, $n=6$; group 2, $n=1$ and group $3, n=1$ ). Unfortunately, birth weight data were not available for a number of subjects, therefore IGF1, OBSL1, CUL7 and CCDC8 gene defects may be missed in some SGA patients with no reported birth weight. Additionally, IGF1R defects with an atypical presentation, i.e. with low IGF1 levels would also be missed by this approach.

\section{Ethical approval}

All patients and/or their parents gave informed consent for genetic testing and this study was approved by the NRES Committee East of England - Cambridge East (REC reference: 11/EE/0515).

\section{Molecular analysis}

Genomic DNA was isolated from peripheral blood leukocytes using the Qiagen DNeasy Kit. Coding exons, including the intronic boundaries of the $G H R$, the $G H R$

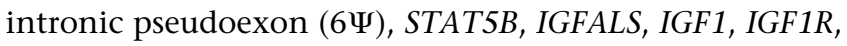
OBSL1, CUL7 and CCDC8 genes were amplified by PCR from genomic DNA. PCR products were visualised on a $1 \%$ agarose gel. Direct sequencing was carried out using standard techniques (primer sequences are available on request). The products were purified and sequenced on an automated DNA sequencer (ABI 3700) according to the manufacturer's instructions. The novel mutations we describe have not previously been reported and were not present in SNP databases including: the Human Gene Mutation Database (HGMD) (http://www.hgmd.cf.ac.uk/ ac/index.php), NHLBI GO Exome Sequencing Project (ESP), Exome Variant Server (accessed February 2014) (http://evs.gs.washington.edu/EVS/), ESP6500 and Ensembl (http://www.ensembl.org/). Multiplex ligationdependent probe amplification (MLPA) was not performed; therefore, gene deletions might have been missed by this methodology.

Two patients were also referred to clinical geneticists by their home institutions. Subsequently, they underwent molecular investigations for Silver-Russell syndrome (SRS), i.e. analysis for maternal uniparental disomy for chromosome 7 (mUPD7) and loss of methylation (LOM) of the 11p15 ICR1 (imprinting control region) telomeric domain as described previously (25). Genetic testing for SRS was not carried out on other subjects in this cohort; therefore, it is possible that other cases of SRS might have been missed.

\section{Statistical analysis}

The differences among the mean height SDS, mean peak GH and mean IGF1 between groups were analysed using an unpaired $t$-test (GraphPad Prism 6, San Diego, CA, USA).

\section{Results}

\section{Mutations identified in the GHI- and IGF1-insensitive patients}

In patients with suspected GHI, mutations were identified

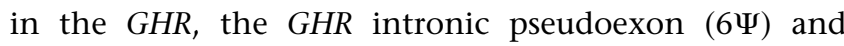
IGFALS genes in 16 out of 69 (23\%) subjects, 12 out of 65 families (19\%). Details of patients and their mutations are given in Table 1 and Fig. 3. The mean height and serum IGF1 SDS of the GHI patients with mutations were -4.6 (range -6.9 to -2.0 ) and -4.1 (range -8.2 to -1.9 ) respectively. Serum IGF1 was undetectable in 50\% $(8 / 16)$ GHI subjects with GHR or IGFALS mutations. The mean peak GH concentration or GH basal values were $37.6 \mu \mathrm{g} / \mathrm{l}$ (range $10.0-119.0 \mu \mathrm{g} / \mathrm{l}) \quad(n=13)$ and $156.8 \mu \mathrm{g} / \mathrm{l}$ (range 12.3-398.0) $(n=3)$.

In 13 out of 69 (19\%) subjects (10/65 families; 15\%) studied, homozygous mutations of the GHR were identified (Fig. 3A). In six out of 13 (46\%) individuals (4/10 families; 40\%), the defect was the previously described intronic pseudoexon GHR mutation (c.618+792A $>$ G; $6 \Psi)$ and, as reported previously, all these patients were of Pakistani origin (23). Two of the six intronic pseudoexon mutation patients were siblings and another two were brothers. These two pairs of siblings and the other individuals with the same mutation were reportedly unrelated. However, we have previously demonstrated that all pseudoexon cases had the same genotype at the GHR locus suggesting a founder effect; therefore, it is likely that these six Pakistani pseudoexon mutation patients also have a common ancestor (23). The less severe phenotype of the subjects with the pseudoexon mutation compared with patients with the other GHR mutations (mean height SDS -3.9 vs -5.9 respectively) can be seen in Fig. 2. Five patients had previously described homozygous GHR mutations: one had a splice site mutation (c.785-6T $>$ A), one a nonsense mutation (c.247C $>$ T) and three unrelated patients had the missense c.703C $>$ T mutation $(26,27,28$, 29). Two brothers had a novel homozygous mutation $($ c. $439+1 \mathrm{G}>\mathrm{A})$ in the GHR, which is predicted to cause a frameshift and be highly damaging. Out of 13 patients, 12 harbouring a homozygous GHR mutation had a 'classical' 


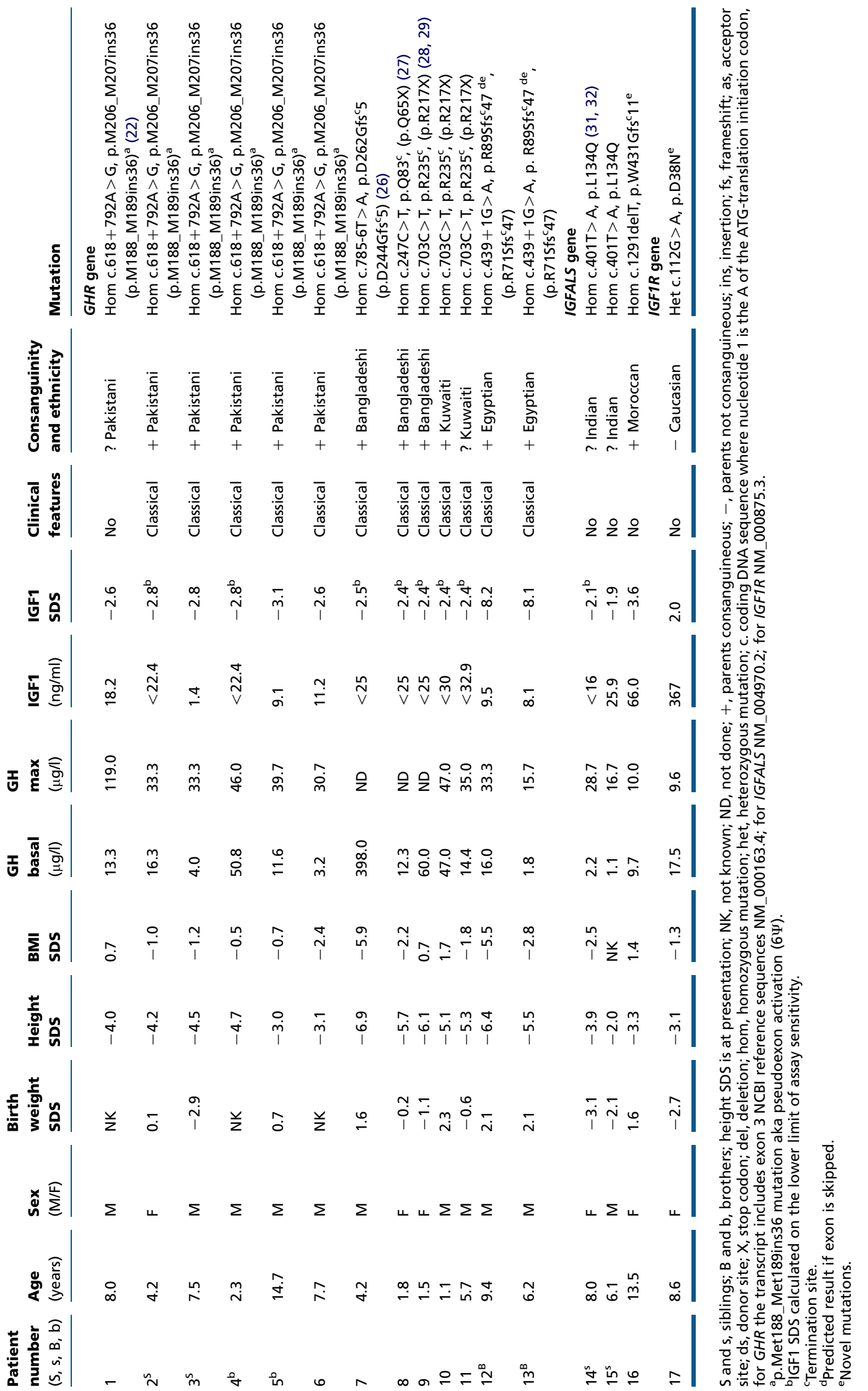




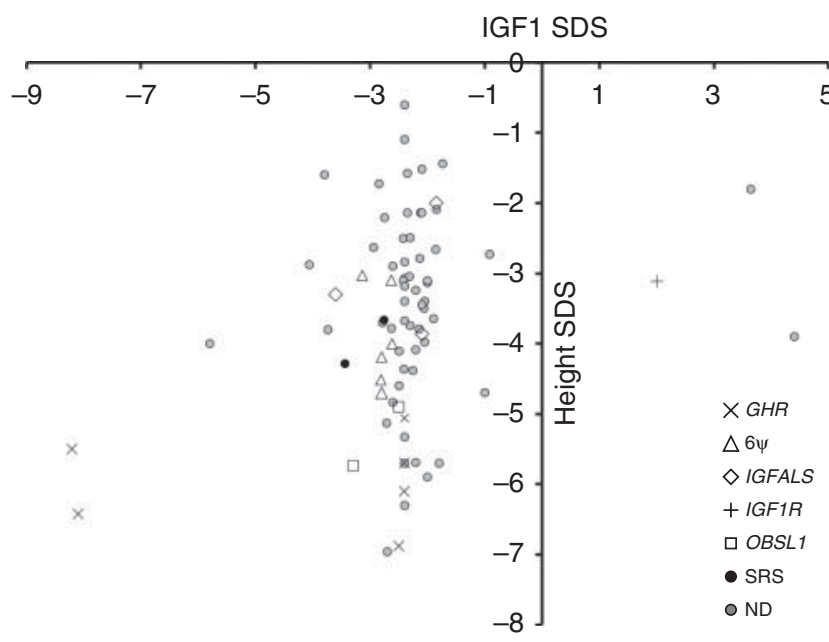

Figure 2

Height SDS and serum IGF1 SDS in patients referred for genotyping $(n=75)$. The less severe phenotype of the subjects

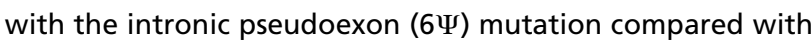
the other homozygous GHR mutations can be clearly observed. The three patients with serum IGF1 SDS $>2$ were the individuals referred with IGF1 insensitivity. SRS, Silver-Russell syndrome; ND, no diagnosis.

Laron facial phenotype (30). The remaining patient with a pseudoexon mutation had normal facial features.

In three $(4 \%)$ of the GHI subjects studied $(2 / 65$ families; 3\%), homozygous mutations of the IGFALS gene were identified (Fig. 3B). Two had a previously described homozygous IGFALS mutation c.401T $>$ A $(31,32)$, and one had a novel c.1291delT mutation. The individual with a novel mutation has been recently published as a case report (33). The novel mutation was a splice site, single-base deletion in exon 2, which was predicted to result in a frameshift leading to a premature stop codon and abolition of the leucine-rich repeats between amino acid residues 574-618, required for protein-protein interactions. This may affect the protein's ability to form a ternary complex with IGF1. The heights of the subjects with IGFALS mutations ranged from -2.0 to -3.9 SDS, the stimulated GH levels were $10-28.7 \mu \mathrm{g} / 1$ and IGF1 SDS were $-3.6,-2.1$ and -1.9 (Fig. 2). Both subjects had undetectable serum IGFALS and IGFBP3. No defects were identified in the seven subjects who underwent STAT5B sequencing.

One of the three patients referred with suspected IGF1 insensitivity had a novel heterozygous missense mutation in the IGF1R gene (c.112G > A; Fig. 3C). Consistent with previous reports (17), she was born SGA (birth weight SDS
-2.7), had childhood short stature (height SDS -3.1) associated with a moderately high IGF1 (SDS 2.0) and an elevated basal GH of $17.5 \mu \mathrm{g} / 1$ (peak GH $9.6 \mu \mathrm{g} / \mathrm{l}$ ) (Fig. 2). This mutation is predicted to be highly damaging in terms of protein function by PolyPhen 2 (http://genetics.bwh. harvard.edu/pph2/) with a score of 1. Parental DNA identified the heterozygous variant in the subject's mother and the father had WT sequence.

\section{Genetic findings in subjects sharing the GHI phenotype}

Genetic defects outside the GH-IGF1 axis were identified in four subjects who also had features of GHI, namely short stature, normal GH secretion and IGF1 deficiency (Table 2). In two subjects who were SGA (birth weight SDS -2.3 and -1.8), hypomethylation in the imprinting control region 11p15 or mUPD7 has been demonstrated confirming SRS (25). The individuals had height and IGF1 SDS of -3.7 and -4.3 , and -2.8 and -3.4 respectively (Fig. 2). Basal GH was $12.7 \mu \mathrm{g} / \mathrm{l}$ in one subject, and peak $\mathrm{GH}$ was $12.5 \mu \mathrm{g} / \mathrm{l}$ in the second. The other two patients had the characteristics of GHI and the dysmorphic features consistent with 3-M syndrome, i.e. frontal bossing, depressed nasal bridge, bitemporal hair thinning and high-pitched voice (34). These subjects also had low birth weights ( -3.2 and -5.2 SDS), short stature (height SDS of -4.9 and -5.7 ) and IGF1 deficiency (SDS of -2.5 and -3.3 ) respectively. Peak GH concentrations were 32.0 and $12.5 \mathrm{ng} / 1$ (Table 2). In these patients, previously described homozygous c1359dupA and c.1465C $>$ T mutations were identified in the OBSL1 gene (Table 2) (35). Another patient had an unknown heterozygous single-base deletion in CCDC8 (p.E16fs*26). No other variants with minor allele frequency (MAF) $<1 \%$ were identified in the genes associated with 3-M syndrome (OBSL1, CUL7 and CCDC8).

\section{Individuals with no diagnosis}

In 51 out of 72 (71\%) patients (32M, 19F) no diagnosis was defined by single gene sequencing (Fig. 1). This comprised a cohort of patients with suspected GHI $(n=49)$ and IGF1 insensitivity $(n=2)$. The GHI patients were of mean age 7.8 years (range $0.4-17.0$ ) and had mean height SDS -3.6 (range -1.5 to -9.4 ) and mean serum IGF1 SDS -2.4 (range -5.8 to -2.0 ). Patients with suspected IGF1 insensitivity had height SDS of -2.4 and -3.9 associated with IGF1 SDS of 3.7 and 4.4 respectively. Therefore, in a significant proportion of GHI- and IGF1-insensitive patients, even those with very severe short stature, 


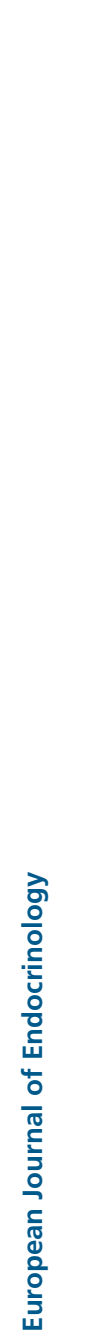

a genetic diagnosis may not be obtained by sequencing of genes known to cause GHI to date.

\section{Diagnostic value of height and IGF1 SDS}

The mean height SDS, mean IGF1 SDS and mean peak GH levels were significantly different in the GHI patients with a homozygous GHR (including the intronic pseudoexon

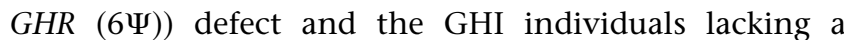
genetic diagnosis. The mean height SDS, mean IGF1 SDS and mean peak GH levels were also significantly different in the GHI patients with either a homozygous GHR, $6 \Psi$ or an IGFALS defect and the GHI individuals lacking a genetic diagnosis. Additionally, the mean height SDS and IGF1 SDS were significantly lower in GHI patients with a genetic

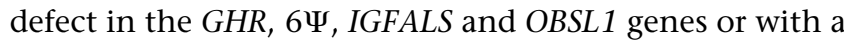
diagnosis of SRS compared with those GHI patients with no genetic diagnosis (Table 3).

\section{Discussion}

The referral of children with short stature who have normal GH secretion is significantly more frequent than those with GH deficiency. The identification of a causative genetic mutation in such a patient can confirm the cause of growth failure and provide information relevant to the growth prognosis. The range of phenotypes expressed as heights in children with GHI has been reported to be broad $(19,20,36)$ and the results reported in this study further confirm the existence of a continuum of genetic and phenotypic abnormalities in GHI subjects (18) and justify the genetic assessment of children with phenotypes ranging from extreme growth failure, as in Laron syndrome, to less severe short stature as in IGFALS mutations (11) and dominant negative GHR defects $(21,37)$. Similarly, the degree of IGF1 deficiency can vary throughout this continuum and depends on the degree of disruption of IGF1 generation induced by a causative mutation (18).

The cohort of subjects we have investigated is predominantly male ( $63 \%$ vs $37 \%)$, similar to the only other comparable published series of 35 short-stature patients with apparent GHI referred for genetic analysis (69\% males vs $31 \%$ females) (24). The explanation for this sex bias is unclear but concurs with other published reports regarding the sex differences in children referred with short stature $(38,39)$. Whether these differences result from the selection bias of families and/or physicians or unrelated factors remains uncertain. 
Table 3 Comparison of mean height SDS, peak GH concentration and IGF1 SDS among the GHI patient groups (groups 1-3) with a genetic defect and the individuals lacking a molecular diagnosis. Means+S.D.

\begin{tabular}{|c|c|c|c|c|c|c|}
\hline Diagnosis & $\begin{array}{l}\text { Mean height } \\
\text { SDS }(n)\end{array}$ & $\begin{array}{l}\text { P value } \\
(95 \% \mathrm{Cl})\end{array}$ & $\begin{array}{c}\text { Mean peak GH, } \\
\mu \mathrm{g} / \mathrm{l}(n)\end{array}$ & $\begin{array}{l}\text { P value } \\
(95 \% \mathrm{Cl})\end{array}$ & $\begin{array}{l}\text { Mean IGF1 } \\
\text { SDS }(n)\end{array}$ & $\begin{array}{l}\text { P value } \\
(95 \% \mathrm{Cl})\end{array}$ \\
\hline No genetic diagnosis & $-3.6 \pm 1.5(49)$ & - & $23.0 \pm 18.0(45)$ & - & $-2.4 \pm 0.7(54)$ & 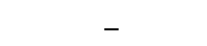 \\
\hline $\begin{array}{l}\text { GHR and GHR6 } \\
\text { mutations }\end{array}$ & $-5.0 \pm 1.2(13)$ & $0.003(0.5-2.3)$ & $43 \pm 28.0(10)$ & 0.006 (5.9 to 34.1$)$ & $-3.5 \pm 2.1(13)$ & $0.002(0.4-1.8)$ \\
\hline 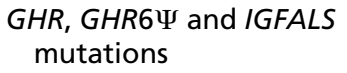 & $-4.6 \pm 1.4(16)$ & $0.022(0.15-1.9)$ & $38 \pm 26.9(13)$ & 0.002 (2.2 to 27.8$)$ & $-3.3 \pm 1.9(16)$ & $0.005(0.3-1.5)$ \\
\hline 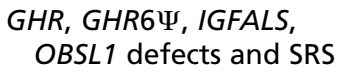 & $-4.6 \pm 2.1(20)$ & $0.029(0.1-1.9)$ & $34 \pm 25.4(17)$ & NS ( -5 to 22.5$)$ & $-3.2 \pm 2.3(20)$ & $0.024(0.1-1.5)$ \\
\hline
\end{tabular}

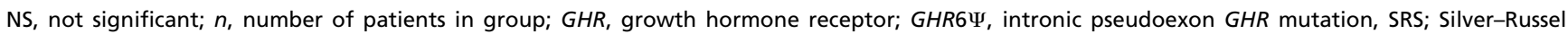
syndrome.

The nature of a pathogenic GH-IGF1 axis mutation can to some extent be predicted by the phenotype and biochemical characteristics of the patient. For example, extreme deficiency of IGF1, IGFBP3 and ALS associated with a relatively mild phenotype would be consistent with a mutation of IGFALS. An intermediate phenotype with moderate deficiency of IGF1 would be a candidate for a pseudoexon or dominant negative GHR mutation $(21,23,40)$. Although very low serum IGF1 levels are predictive of a genetic mutation, particularly a homozygous GHR (but not the intronic pseudoexon) defect, in the rest of the cohort, there is considerable overlap of patients with and without a defined genetic diagnosis. This may reflect the wide variability and the sensitivity of the IGF1 assays, as a significant proportion of patients ( $28 \%$ in the whole cohort, $50 \%$ of patients with a genetic diagnosis) had serum IGF1 levels less than the lower limit of the assay, i.e. undetectable. It was regrettable that central determination of serum IGF1 was not possible.

The relationship of the severity of the short stature to the prevalence of GH-IGF1 mutations has not yet been clearly defined. As expected, patients with homozygous GHR mutations (but not the pseudoexon intronic mutation) have the most extreme phenotypes of our cohort. Wit et al. (24) have reported more genetic variants in children with heights $<-2.5$ s.D. compared with those with less severe short stature. It would be logical for this finding to be confirmed, as mutations altering the function of key proteins in the GH-IGF1 axis would be expected to be more prevalent in children with severe growth failure. Our data suggest that there is an increased likelihood of finding a genetic mutation in individuals with height SDS $\leq-2.5$ and IGF1 SDS $\leq 2.0$. However, we also demonstrate that it is possible to have severe short stature and have no identifiable defects in the genes known to cause GHI. Additionally, genetic defects such as

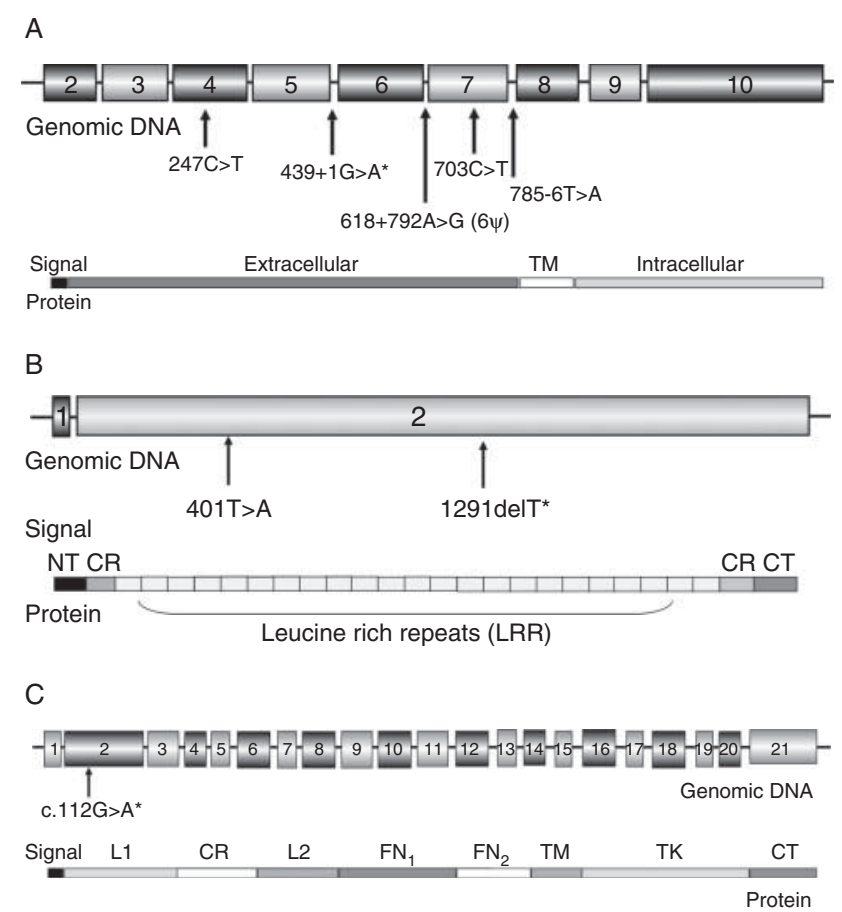

\section{Figure 3}

GH-IGF1 axis gene mutations identified. Schematics of the genomic DNAs and protein structures, the signal peptides and protein domains are encoded by the corresponding exons as indicated. The coding exons of the genomic DNA are numbered. (A) Homozygous growth hormone receptor (GHR) mutations. *Novel splice mutation situated in intron 5.

(B) Homozygous IGFALS mutations. *Novel frameshift mutation situated in exon 2. (C) *Novel heterozygous IGF1R missense mutation situated in exon 2. Signal, signal peptide; TM, transmembrane domain; NT, N-terminal domain; CR, cysteinerich domain, CT, C-terminal domain; L1 and L2, L-domains; $\mathrm{FN}_{1}$ and $\mathrm{FN}_{2}$, fibronectin domains; $\mathrm{TK}$, tyrosine kinase domain. 
homozygous IGFALS mutations may rarely be found in patients with less severe phenotypes (height SDS -1.5 to -2.0 IGF1 > 2.0), hence genetic assessment should still be considered in this patient group, especially if the clinical suspicion is high and/or there is a family history of short stature.

It is therefore important to consider the clinical (particularly height SDS) and biochemical information before embarking on genetic investigation. The cohort we investigated included subjects with a wide range of phenotypes and ages at presentation. We also recognise that our cohort incorporates a selected group of subjects. However, in the subjects with suspected GHI, a combination of a very low serum IGF1 and height SDS increased the likelihood of a genetic defect being discovered, as both were significantly lower in the subjects with a genetic diagnosis compared with those lacking a molecular diagnosis. Additionally, peak GH levels were significantly higher in the GHI subjects with homozygous GHR/intronic GHR pseudoexon mutations compared with the subjects with no molecular diagnosis. Interestingly, there was no overlap of height SDS with patients who had intronic GHR pseudoexon mutations and those with other homozygous GHR mutations. A characteristic phenotype in the group of patients with an intronic GHR pseudoexon defect has been suggested, as proposed previously (23). The high number of intronic GHR pseudoexon mutations identified in our cohort compared with other genetic defects probably reflects the consanguinity in certain ethnic communities within the UK.

The prevalence of heterozygous mutations of GHIGF1 axis genes has been reported since the early molecular analysis of subjects with possible $G H R$ mutations (Fig. 3). Despite the finding of heterozygous GHR mutations in subjects with idiopathic short stature (41), no clear proof exists that such mutations, with the exception of the dominant negative splice site mutation (21), affect GHR function sufficiently to cause a short stature phenotype. However, there is evidence that heterozygous IGFALS mutations can influence growth, with a more subtle effect of $\sim 1.0$ s.D. being demonstrated compared with WT subjects and an additional 1.0-1.5 s.D. in subjects with homozygous defects $(31,42)$. The suggestion has also recently been made that heterozygous mutations of two or more growth-regulating genes may combine to induce a short stature phenotype (24).

Defects of IGF1 action are characterised by impaired foetal growth; therefore, a combination of impaired foetal and postnatal growth is suggestive of either $I G F 1$ or $I G F 1 R$ mutations. Heterozygous $I G F 1 R$ mutations and $I G F 1 R$ gene deletions are a recognised cause of short stature associated with intrauterine growth retardation, microcephaly, developmental delay and micrognathia (18). One patient who was referred with suspected IGF1 insensitivity was found to have a heterozygous IGF1R mutation. This subject presented with the classical phenotype of pre- and postnatal growth failure associated with a moderately high IGF1. This suggests that genetic analysis can also be helpful in the assessment of children with suspected IGF1 insensitivity, particularly those with serum IGF1 SDS $>2.0$ and height SDS $<-2.0$. Although this was not undertaken in this study, MLPA analysis is also recommended to detect IGF1R gene deletions.

The features of GHI, namely short stature, normal GH and low IGF1, are relatively crude and it is not surprising that they may be seen in a number of other growth disorders. We identified two such disorders, SRS and 3-M syndrome. Pathogenic mutations consistent with these diagnoses were identified emphasising the critical importance of accurate clinical phenotyping. In the subjects with SRS, careful clinical assessment, as published, may have suggested the diagnosis $(25,43)$. Similarly, the key features of 3-M syndrome which are pre- and postnatal growth restriction, prominent heels, facial dysmorphism (triangular shaped face, anteverted nares and full fleshy lips), normal intelligence and radiological features (slender long bones and tall vertebral bodies) are now being increasingly recognised as this disorder enters into the differential diagnosis of children with possible GHI (35).

In conclusion, the findings reported in this study demonstrate that genetic defects can be identified in children presenting with short stature and features of GHI or IGF1 insensitivity and confirm the existence of a continuum of genetic and phenotypic abnormalities. Knowledge of the clinical and biochemical features associated with such mutations may help to orientate the clinician and the molecular scientist to the most likely candidate gene to be affected. Additionally, careful evaluation of height SDS and serum IGF1 SDS before referral for genetic testing may improve the diagnostic yield. Definition of a causative mutation can contribute to clinical management by confirming and clarifying the aetiology of the short stature, by supplementing information on long-term growth prognosis and by providing the basis for genetic counselling.

Declaration of interest

The authors declare that there is no conflict of interest that could be perceived as prejudicing the impartiality of the research reported. 
Funding

$H \mathrm{~L}$ Storr received a research grant from Ipsen UK to undertake the genetic sequencing project.

\section{Acknowledgements}

The authors are very grateful to Ipsen UK for funding this genetic sequencing service. They are also grateful to patients, their families and all the referring clinicians particularly Marc Maes (University Hospital, Brussels, Belgium), Dina Ramadan (Sabah Hospital, Kuwait), Sameh Tawfik (Cairo, Egypt), Iman Al Basiri (Mubarak Al-Kabeer Hospital, Kuwait), Steve Rose (Birmingham Heartlands \& Solihull NHS Trust, UK), Talat Mushtaq (Leeds University Teaching Hospitals, UK) and Joanne Walker (Queen Alexandra Hospital, Portsmouth, UK).

\section{References}

1 Savage MO, Burren CP \& Rosenfeld RG. The continuum of growth hormone-IGF-I axis defects causing short stature: diagnostic and therapeutic challenges. Clinical Endocrinology 201072 721-728. (doi:10.1111/j.1365-2265.2009.03775.x)

2 Laron Z, Pertzelan A \& Mannheimer S. Genetic pituitary dwarfism with high serum concentation of growth hormone - a new inborn error of metabolism? Israel Journal of Medical Sciences 19662 152-155.

3 Godowski PJ, Leung DW, Meacham LR, Galgani JP, Hellmiss R, Keret R, Rotwein PS, Parks JS, Laron Z \& Wood WI. Characterization of the human growth hormone receptor gene and demonstration of a partial gene deletion in two patients with Laron-type dwarfism. PNAS 198986 8083-8087. (doi:10.1073/pnas.86.20.8083)

4 Amselem S, Duquesnoy P, Attree O, Novelli G, Bousnina S, Postel-Vinay MC \& Goossens M. Laron dwarfism and mutations of the growth hormone-receptor gene. New England Journal of Medicine 1989321 989-995. (doi:10.1056/NEJM198910123211501)

5 Rosenfeld RG, Rosenbloom AL \& Guevara-Aguirre J. Growth hormone (GH) insensitivity due to primary GH receptor deficiency. Endocrine Reviews 199415 369-390. (doi:10.1210/edrv-15-3-369)

6 Kofoed EM, Hwa V, Little B, Woods KA, Buckway CK, Tsubaki J, Pratt KL, Bezrodnik L, Jasper H, Tepper A et al. Growth hormone insensitivity associated with a STAT5b mutation. New England Journal of Medicine 2003349 1139-1147. (doi:10.1056/NEJMoa022926)

7 Rosenfeld RG, Belgorosky A, Camacho-Hubner C, Savage MO, Wit JM \& Hwa V. Defects in growth hormone receptor signaling. Trends in Endocrinology and Metabolism 200718 134-141. (doi:10.1016/j.tem. 2007.03.004)

8 Woods KA, Camacho-Hubner C, Savage MO \& Clark AJ. Intrauterine growth retardation and postnatal growth failure associated with deletion of the insulin-like growth factor I gene. New England Journal of Medicine 1996335 1363-1367. (doi:10.1056/NEJM199610313351805)

9 Netchine I, Azzi S, Le Bouc Y \& Savage MO. IGF1 molecular anomalies demonstrate its critical role in fetal, postnatal growth and brain development. Best Practice \& Research. Clinical Endocrinology \& Metabolism 201125 181-190. (doi:10.1016/j.beem.2010.08.005)

10 Domene HM, Bengolea SV, Martinez AS, Ropelato MG, Pennisi P, Scaglia P, Heinrich JJ \& Jasper HG. Deficiency of the circulating insulinlike growth factor system associated with inactivation of the acid-labile subunit gene. New England Journal of Medicine 2004350 570-577. (doi:10.1056/NEJMoa013100)

11 Domene HM, Hwa V, Argente J, Wit JM, Camacho-Hubner C, Jasper HG, Pozo J, van Duyvenvoorde HA, Yakar S, FofanovaGambetti OV et al. Human acid-labile subunit deficiency: clinical, endocrine and metabolic consequences. Hormone Research 200972 129-141. (doi:10.1159/000232486)
12 Abuzzahab MJ, Schneider A, Goddard A, Grigorescu F, Lautier C, Keller E, Kiess W, Klammt J, Kratzsch J, Osgood D et al. IGF-I receptor mutations resulting in intrauterine and postnatal growth retardation. New England Journal of Medicine 2003349 2211-2222. (doi:10.1056/ NEJMoa010107)

13 Klammt J, Kiess W \& Pfaffle R. IGF1R mutations as cause of SGA. Best Practice \& Research. Clinical Endocrinology \& Metabolism 201125 191-206. (doi:10.1016/j.beem.2010.09.012)

14 Savage MO, Attie KM, David A, Metherell LA, Clark AJ \& Camacho-Hubner C. Endocrine assessment, molecular characterization and treatment of growth hormone insensitivity disorders. Nature Clinical Practice. Endocrinology \& Metabolism 20062 395-407. (doi:10.1038/ncpendmet0195)

15 Kiess W \& Pfaeffle R. Preface. The rapid increase of knowledge in genetic causes of growth disorders. Best Practice \& Research. Clinical Endocrinology \& Metabolism 201125 vii-viii. (doi:10.1016/j.beem.2010. 10.016)

16 Caliebe J, Broekman S, Boogaard M, Bosch CA, Ruivenkamp CA, Oostdijk W, Kant SG, Binder G, Ranke MB, Wit JM et al. IGF1, IGF1R and SHOX mutation analysis in short children born small for gestational age and short children with normal birth size (idiopathic short stature). Hormone Research in Paediatrics 201277 250-260. (doi:10.1159/000338341)

17 Ester WA, van Duyvenvoorde HA, de Wit CC, Broekman AJ Ruivenkamp CA, Govaerts LC, Wit JM, Hokken-Koelega AC \& Losekoot M. Two short children born small for gestational age with insulin-like growth factor 1 receptor haploinsufficiency illustrate the heterogeneity of its phenotype. Journal of Clinical Endocrinology and Metabolism 200994 4717-4727. (doi:10.1210/jc.2008-1502)

18 David A, Hwa V, Metherell LA, Netchine I, Camacho-Hubner C, Clark AJ, Rosenfeld RG \& Savage MO. Evidence for a continuum of genetic, phenotypic, and biochemical abnormalities in children with growth hormone insensitivity. Endocrine Reviews 201132 472-497. (doi:10.1210/er.2010-0023)

19 Woods KA, Dastot F, Preece MA, Clark AJ, Postel-Vinay MC, Chatelain PG, Ranke MB, Rosenfeld RG, Amselem S \& Savage MO. Phenotype:genotype relationships in growth hormone insensitivity syndrome. Journal of Clinical Endocrinology and Metabolism 199782 3529-3535. (doi:10.1210/jcem.82.11.4389)

20 Burren CP, Woods KA, Rose SJ, Tauber M, Price DA, Heinrich U, Gilli G Razzaghy-Azar M, Al-Ashwal A, Crock PA et al. Clinical and endocrine characteristics in atypical and classical growth hormone insensitivity syndrome. Hormone Research 200155 125-130. (doi:10.1159/ 000049983)

21 Ayling RM, Ross R, Towner P, Von Laue S, Finidori J, Moutoussamy S, Buchanan CR, Clayton PE \& Norman MR. A dominant-negative mutation of the growth hormone receptor causes familial short stature. Nature Genetics 1997 16 13-14. (doi:10.1038/ng0597-13)

22 Metherell LA, Akker SA, Munroe PB, Rose SJ, Caulfield M, Savage MO, Chew SL \& Clark AJ. Pseudoexon activation as a novel mechanism for disease resulting in atypical growth-hormone insensitivity. American Journal of Human Genetics 200169 641-646. (doi:10.1086/323266)

23 David A, Camacho-Hubner C, Bhangoo A, Rose SJ, Miraki-Moud F Akker SA, Butler GE, Ten S, Clayton PE, Clark AJ et al. An intronic growth hormone receptor mutation causing activation of a pseudoexon is associated with a broad spectrum of growth hormone insensitivity phenotypes. Journal of Clinical Endocrinology and Metabolism 200792 655-659. (doi:10.1210/jc.2006-1527)

24 Wit JM, van Duyvenvoorde HA, Scheltinga SA, de Bruin S, Hafkenscheid L, Kant SG, Ruivenkamp CA, Gijsbers AC, van Doorn J, Feigerlova E et al. Genetic analysis of short children with apparent growth hormone insensitivity. Hormone Research in Paediatrics 201277 320-333. (doi:10.1159/000338462)

25 Netchine I, Rossignol S, Dufourg MN, Azzi S, Rousseau A, Perin L, Houang M, Steunou V, Esteva B, Thibaud N et al. 11p15 imprinting center region 1 loss of methylation is a common and specific cause of 
typical Russell-Silver syndrome: clinical scoring system and epigeneticphenotypic correlations. Journal of Clinical Endocrinology and Metabolism 200792 3148-3154. (doi:10.1210/jc.2007-0354)

26 David A, Miraki-Moud F, Shaw NJ, Savage MO, Clark AJ \& Metherell LA. Identification and characterisation of a novel GHR defect disrupting the polypyrimidine tract and resulting in GH insensitivity. European Journal of Endocrinology 2010162 37-42. (doi:10.1530/EJE-09-0583)

27 Sobrier ML, Dastot F, Duquesnoy P, Kandemir N, Yordam N, Goossens $\mathrm{M} \&$ Amselem $\mathrm{S}$. Nine novel growth hormone receptor gene mutations in patients with Laron syndrome. Journal of Clinical Endocrinology and Metabolism 199782 435-437. (doi:10.1210/jcem.82. 2.3725)

28 Amselem S, Duquesnoy P, Duriez B, Dastot F, Sobrier ML, Valleix S \& Goossens M. Spectrum of growth hormone receptor mutations and associated haplotypes in Laron syndrome. Human Molecular Genetics 19932 355-359. (doi:10.1093/hmg/2.4.355)

29 Berg MA, Argente J, Chernausek S, Gracia R, Guevara-Aguirre J, Hopp M, Perez-Jurado L, Rosenbloom A, Toledo SP \& Francke U. Diverse growth hormone receptor gene mutations in Laron syndrome. American Journal of Human Genetics 199352 998-1005.

30 Laron Z. Laron syndrome (primary growth hormone resistance or insensitivity): the personal experience 1958-2003. Journal of Clinical Endocrinology and Metabolism 200489 1031-1044. (doi:10.1210/jc. 2003-031033)

31 Fofanova-Gambetti OV, Hwa V, Kirsch S, Pihoker C, Chiu HK, Hogler W, Cohen LE, Jacobsen C, Derr MA \& Rosenfeld RG. Three novel IGFALS gene mutations resulting in total ALS and severe circulating IGF-I/IGFBP-3 deficiency in children of different ethnic origins. Hormone Research 200971 100-110. (doi:10.1159/000183899)

32 David A, Rose SJ, Miraki-Moud F, Metherell LA, Savage MO, Clark AJ \& Camacho-Hubner C. Acid-labile subunit deficiency and growth failure: description of two novel cases. Hormone Research in Paediatrics 201073 328-334. (doi:10.1159/000308164)

33 Poukoulidou T, Kowalczyk J, Metherell L, De Schepper J \& Maes M. A novel homozygous mutation of the IGFALS gene in a female adolescent: indirect evidence for a contributing role of the circulating IGF-I pool in the pubertal growth spurt. Hormone Research in Paediatrics 201481 422-427. (doi:10.1159/000358329)

34 Clayton PE, Hanson D, Magee L, Murray PG, Saunders E, AbuAmero SN, Moore GE \& Black GC. Exploring the spectrum of 3-M syndrome, a primordial short stature disorder of disrupted ubiquitination. Clinical Endocrinology 201277 335-342. (doi:10.1111/j.1365-2265. 2012.04428.x)
35 Hanson D, Murray PG, Sud A, Temtamy SA, Aglan M, Superti-Furga A, Holder SE, Urquhart J, Hilton E, Manson FD et al. The primordial growth disorder 3-M syndrome connects ubiquitination to the cytoskeletal adaptor OBSL1. American Journal of Human Genetics 2009 84 801-806. (doi:10.1016/j.ajhg.2009.04.021)

36 Guevara-Aguirre J, Vasconez O, Martinez V, Martinez AL, Rosenbloom AL, Diamond FB Jr, Gargosky SE, Nonoshita L \& Rosenfeld RG. A randomized, double blind, placebo-controlled trial on safety and efficacy of recombinant human insulin-like growth factor-I in children with growth hormone receptor deficiency. Journal of Clinical Endocrinology and Metabolism 199580 1393-1398. (doi:10.1210/jcem. 80.4.7536209)

37 Iida K, Takahashi Y, Kaji H, Nose O, Okimura Y, Abe H \& Chihara K. Growth hormone $(\mathrm{GH})$ insensitivity syndrome with high serum GH-binding protein levels caused by a heterozygous splice site mutation of the GH receptor gene producing a lack of intracellular domain. Journal of Clinical Endocrinology and Metabolism $1998 \mathbf{8 3}$ 531-537. (doi:10.1210/jcem.83.2.4601)

38 Sisley S, Trujillo MV, Khoury J \& Backeljauw P. Low incidence of pathology detection and high cost of screening in the evaluation of asymptomatic short children. Journal of Pediatrics 2013163 1045-1051. (doi:10.1016/j.jpeds.2013.04.002)

39 Grimberg A, Kutikov JK \& Cucchiara AJ. Sex differences in patients referred for evaluation of poor growth. Journal of Pediatrics $2005 \mathbf{1 4 6}$ 212-216. (doi:10.1016/j.jpeds.2004.09.009)

40 lida K, Kurita K, Tange K \& Yoshida K. Necrosis of the articular tubercle after repeated injections of sodium hyaluronate in the temporomandibular joint. A case report. International Journal of Oral and Maxillofacial Surgery 199827 278-279. (doi:10.1016/S0901-5027(05)80614-9)

41 Goddard AD, Covello R, Luoh SM, Clackson T, Attie KM, Gesundheit N, Rundle AC, Wells JA \& Carlsson LM. Mutations of the growth hormone receptor in children with idiopathic short stature. The Growth Hormone Insensitivity Study Group. New England Journal of Medicine 1995333 1093-1098. (doi:10.1056/NEJM199510263331701)

42 Domene HM, Scaglia PA, Martinez AS, Keselman AC, Karabatas LM, Pipman VR, Bengolea SV, Guida MC, Ropelato MG, Ballerini MG et al. Heterozygous IGFALS gene variants in idiopathic short stature and normal children: impact on height and the IGF system. Hormone Research in Paediatrics 201380 413-423. (doi:10.1159/000355412)

43 Dias RP, Nightingale P, Hardy C, Kirby G, Tee L, Price S, Macdonald F, Barrett TG \& Maher ER. Comparison of the clinical scoring systems in Silver-Russell syndrome and development of modified diagnostic criteria to guide molecular genetic testing. Journal of Medical Genetics 201350 635-639. (doi:10.1136/jmedgenet-2013-101693)

Received 30 June 2014

Revised version received 6 November 2014

Accepted 18 November 2014 